\title{
Conservation efforts of an important medicinal plant (Taxus baccata Linn.) in West Kameng district of Arunachal Pradesh (India)
}

\author{
Gibji Nimasow ${ }^{1,}$, , Oyi Dai Nimasow ${ }^{2}$, Jawan Singh Rawat ${ }^{3}$, Leki Norbu ${ }^{4}$ \\ ${ }^{1}$ Department of Geography, Rajiv Gandhi University, Doimukh, Itanagar, Arunachal Pradesh, India \\ ${ }^{2}$ Department of Botany, Rajiv Gandhi University, Doimukh, Itanagar, Arunachal Pradesh, India \\ ${ }^{3}$ Department of Geography, Government Degree College, Chaukhutia, Uttarakhand, India \\ ${ }^{4}$ Department of Geography, Government College, Bomdila, Arunachal Pradesh, India
}

\section{Email address:}

gibji26@yahoo.co.in (G. Nimasow), oyidai07@yahoo.com (O. D. Nimasow),jsr_06@rediffmail.com (J. S. Rawat), leki76@rediffmail.com (L. Norbu)

\section{To cite this article:}

Gibji Nimasow, Oyi Dai Nimasow, Jawan Singh Rawat, Leki Norbu. Conservation Efforts of an Important Medicinal Plant (Taxus baccata Linn.) in West Kameng District of Arunachal Pradesh (India). Earth Sciences. Special Issue: Conservation of Taxus Baccata Linn (Yew). Vol. 4, No. 3-1, 2015, pp. 1-10. doi: 10.11648/j.earth.s.2015040301.11

\begin{abstract}
Taxus is a small to medium sized tree, with red 'berries' (seed covered by arils), valuable for taxol or paclitaxel extraction used in the preparation of anti-cancer drugs (breast cancer and ovarian cancer), kaposi's sarcoma (an AIDS related cancer) and over 20 such other indications. It is an evergreen tree found in the temperate forests with an altitude ranging between $1500 \mathrm{~m}$ to $3000 \mathrm{~m}$. The worldwide demand of the taxol is $800-1000 \mathrm{~kg}$ annually. Around 2 to 3 million $\mathrm{kg}$ of biomass is harvested annually where as the sustainable rate of harvesting is estimated to be 0.6 million $\mathrm{kg}$ per year. Although, the endophytes isolated from the Taxus when cultured in the medium are found to grow taxol, but the rate is very low. The maximum occurrence and high exploitation of Taxus has been reported from West Kameng district of Arunahal Pradesh, until the prohibition on its export through listing under Negative Lists of Exports by Government of India in 1996. Random linear transacts in the deep forests recorded a total of 145 Taxus plants. Out of which, 105 are dead trees and only 38 are live plants. Among the 38 live plants 20 are seedlings, 14 are saplings and 4 are full grown trees - one each near Sanglem and New Bomdila and another two between Ramda and Palizi. Therefore, conservation efforts like workshops, seminars, talks, distribution of pamphlets, pasting of posters and mass plantation has been organized by involving the villagers. The study attempts to explore the current status of Taxus in the aftermath of large scale trade occurred during 1990s and generate community awareness for conservation and regeneration of the important medicinal plant.
\end{abstract}

Keywords: Conservation, Taxus, Cancer, Taxol, Workshops

\section{Introduction}

Taxus baccata Linn. is valuable for taxol or paclitaxel extraction [1] used in the preparation of anti-cancer drugs, in addition to other medical uses in Ayurveda and Tibetan medicine [2]. The ideal altitudinal zone where the tree occurs is between 2000 to $2500 \mathrm{~m}$ [3]. Taxus can be propagated through branch cuttings and this feature is so particularly relevant to its cultivation efforts [4]. Dabur India Ltd., a large manufacturer of plant-based medicines is propagating the species through cuttings and then distributing the seedlings to farmers to grow under contract [1]. Taxus occurs in the states of Jammu and Kashmir, Himachal Pradesh, Uttar Pradesh,
Sikkim, West Bengal, Arunachal Pradesh, Meghalaya, Nagaland and Manipur [5]. It is also reported from the Himalayan countries of Nepal and Bhutan [6]. Taxol, a highly derivatised diterpenoid, has shown promises as an anti-tumor agent in breast and ovarian cancer. Taxol was first isolated from the bark of Taxus brevifolia [7], but in India and other parts of the world pharmaceutical companies have succeeded in isolating it from the leaves [8]. Although all 11 species of Taxus make taxol, the natural stands of these trees are often small and remote [9]. Moreover, only 0.01 to $0.03 \%$ of the dry phloem weight is taxol, yet as much as $2 \mathrm{~g}$ of purified taxol is 
required for a full regimen of anti-tumor treatment [10]. It is reported that a 20 year old tree can yield up to $30 \mathrm{~kg}$ of leaves and $5 \mathrm{~kg}$ of barks which in turn produce $4 \mathrm{gm}$ of taxol priced at Rs. 3 lakhs at a very conservative estimate [4]. The worldwide demand of the taxol is $800-1000 \mathrm{~kg}$ annually. The demand is growing at the annual rate of $20 \%$. The estimated $30,000 \mathrm{~kg}$ of the biomass of Taxus baccata is needed to produce $1 \mathrm{~kg}$ of the paclitaxel. Around 2 to 3 million $\mathrm{kg}$ of biomass is harvested annually where as the sustainable rate of harvesting is estimated to be 0.6 million $\mathrm{kg}$ per year [11]. It was noticed that the growth and survival of this species declined significantly when the bark was removed beyond a limit of average bark thickness of $0.43 \mathrm{~cm}$ [8].

Since the first taxol-producing fungus Taxomyces andreanae isolated in 1993, there have been few reports on isolation of taxol-producing endophytic fungi demonstrating that organism other than Taxus spp. could produce Taxol [12, 13]. Over the last decade there has been a great deal of interest in finding other fungi that produce taxol [14]. Several taxol-producing fungi have been identified, such as Taxomyces andrenae, Pestalotiopsis microspora, Alternaria spp., Fusarium latritium and Periconia spp. [15, 16, 17, 18, 19]. Although, the endophytes isolated from the Taxus when cultured in the medium are found to grow taxol, but the rate is very low. P. Microspora isolated from Taxus wallichiana produces $60-70 \mu \mathrm{g} / \mathrm{l}$ culture whereas the yield from other species is less than $2 \mu \mathrm{g} / 1$ of paclitaxel [3]. All other alternatives for paclitaxel production, such as chemical synthesis, genetic engineering and tissue and cell cultures of Taxus species are expensive and give low yields [20, 21]. Presently, all taxol in the world's market has its origin from the Taxus spp. [12].

The high demand of the plant for its anticancer properties coupled with low yields and slow-growing nature of the tree resulted in decimation of the species. European yew Taxus baccata, taxonomically very close to Himalayan yew and possibly the same species, is used for production of taxol but it has led to over-exploitation along the Himalayas. Taxus baccata is a medicinal plant of the alpine zone in the North Eastern States of India. The ideal altitudinal zone where the tree occurs is between 2000 to $2500 \mathrm{~m}$ throughout Arunachal Pradesh in the temperate forest of Bomdila, Shergaon, Eagle Nest, Dirang, Thungri, Tawang, Mago and Zemithang in West Kameng and Tawang Districts, Tale Valley (few trees only) of Lower Subansiri, Anini, Mayodiya in Dibang Valley district, Mechuka in Siang and Melinja and Hotspring areas of Lohit District [3]. In the recent years, the extensive and indiscriminate collection of Taxus baccata has posed a serious threat to this important Himalayan tree [22]. It is reported that clandestine trading in the species is already taking place in some states where young saplings raised by the locals are being collected by the agents and sold abroad through an established network. Major commercial and drug manufacturing units located outside the state employ local agents, mainly in West Kameng. The agents gets the Taxus leaves collected with the help of local villagers who employ professional collectors/labourers [5]. Moreover, the profits are being garnered mainly by the drug manufacturers and middlemen, to the neglect of the local people [23]. Grassroots Options (2002) also highlights the deeply entrenched nexus of forest official, local contractors and politicians in Taxus trade in Arunachal Pradesh. West Kameng district lies approximately between $91^{\circ} 30^{\prime}$ to $92^{\circ} 40^{\prime}$ East longitudes and $26^{\circ} 54^{\prime}$ to $28^{\circ} 01^{\prime}$ North latitudes (Figure 1).

\section{Methodology}

Detailed survey of available literature was conducted by consulting journals, books, reports, etc. A pilot survey was carried out for preliminary idea of the occurrence of Taxus baccata and also to establish liaison with locals and officials. Intensive field survey was carried out to locate the plant species. Digital Elevation Model (DEM) of the Shuttle Radar Topographic Mission was downloaded from the seamless server of United States Department of Agriculture (USDA). Intensive transact surveys with the help of local experts, hunters, semi-nomadic herder, etc. were conducted randomly to locate the Taxus trees. Information was also collected through informal interaction with the villagers. Global Positioning System (GPS) was used to record the latitude, longitude and altitude of the plant. At each GPS point of Taxus, soil temperature, ph; moisture, etc. were recorded. Soil samples were collected for laboratory analysis. The plant leaves were also collected to maintain herbarium for further systematic taxonomic study. Conservation strategies through awareness campaign, workshops, poster display, pamphlets, calendar, talks, etc. are carried out in the area. In the workshop pamphlets containing the information of the plant were distributed to the villagers, schools, offices and to the military personnel. Similar information were inscribed in the New Year calendar and distributed in the villages. The poster containing messages "Do not kill me, Cancer may kill you" and "Help! Me to grow up, I may help you in curing cancer" both in English and local language are displayed at the crucial points.

\section{Results}

Linear transacts were laid in the vicinity of the localities like Domkho, Morshing, Sanglem, Khelang, Phudung, Mandala, Dirang, Bomdila, New Bomdila, Tenga, Rupa, Kalaktang, Bhalukpong and Palizi-Ramda to assess the availability and status of the Taxus. During the random linear transact around these localities a total of 145 Taxus plants were recorded. Out of which, 105 are dead trees and only 38 are live plants. Among the 38 live plants 20 are seedlings, 14 are saplings and 4 are full grown trees - one each near Sanglem and New Bomdila and another two between Ramda and Palizi. The scattered diagram (Figure 2) shows that maximum numbers of plant are concentrated within the altitudinal range of 1800 to $3000 \mathrm{~m}$. Only in case of Palizi it is located in between 1000 to $1500 \mathrm{~m}$ altitude and few scattered plants are found above $3000 \mathrm{~m}$ i.e. Near Mandala top. This indicates much localized distribution of the species, limited by altitudinal range or other favourable conditions 
which certainly have its implications on the regeneration steps. Litter decomposed black soil, brown soil, blackish brown, sandy soil with small pebbles are the soil types observed during the field survey. The live Taxus plants in Sanglem, Domkho, Morshing, Mandala, etc. are found in the elevation range of 2017 to $3185 \mathrm{~m}$. The soil temperature ranges from $1{ }^{\circ} \mathrm{C}$ at Mandala top to $10.0^{\circ} \mathrm{C}$ near Saglem village with an average of $7.36 \pm 3.42(46.5 \%)$. Similarly the ph value of the points where live Taxus plants were located varies from 4.8 to 6.7 with an average of $6.11 \pm 0.63(10.25)$. On the other hand, soil moisture varies from $9.5 \%$ in the Sanglem to $46 \%$ at Mandala top with an average of 26.52 \pm 13.14 (Table 1).

Table 1. Description of soil collection sites of Taxus baccata in West Kameng.

\begin{tabular}{|c|c|c|c|c|c|c|c|c|}
\hline Site & $\begin{array}{l}\text { Latitude/ } \\
\text { Longitude }\end{array}$ & $\begin{array}{l}\text { Height } \\
\text { (in m) }\end{array}$ & $\begin{array}{l}\text { Pressure } \\
\text { (in mb) }\end{array}$ & $\begin{array}{l}\text { Soil Temp } \\
\left(\text { in }{ }^{\circ} \mathrm{C}\right)\end{array}$ & $\mathbf{P h}$ & $\begin{array}{l}\text { Soil moisture } \\
\text { (in \%) }\end{array}$ & Soil type with colour & $\begin{array}{l}\text { Dominant } \\
\text { vegetation }\end{array}$ \\
\hline $\begin{array}{l}\text { Domkho } \\
\text { (Khebrong) }\end{array}$ & $\begin{array}{l}27^{\circ} 10.072^{\prime} \mathrm{N} \\
92^{\circ} 13.490^{\prime} \mathrm{E}\end{array}$ & 2103 & 792.9 & - & 5.8 & 35 & $\begin{array}{l}\text { Litter decomposed black } \\
\text { forest soil }\end{array}$ & $\begin{array}{l}\text { Wild Tezpatta, white } \\
\text { champa }\end{array}$ \\
\hline Khebrong & $\begin{array}{l}27^{\circ} 10.79^{\prime} \mathrm{N} \\
92^{\circ} 13.494 \mathrm{E}\end{array}$ & 2101 & 793.6 & - & 5.8 & 35 & $\begin{array}{l}\text { Litter decomposed } \\
\text { brown soil with pebbles } \\
2-3 \mathrm{~cm} \mathrm{~d}\end{array}$ & $\begin{array}{l}\text { Gulesiang, } \\
\text { Tongpasiang \& } \\
\text { Badebjone (creeper) }\end{array}$ \\
\hline $\begin{array}{l}\text { Domkho } \\
\text { (Melongkar) }\end{array}$ & $\begin{array}{l}27^{\circ} 10^{\prime} 30.6^{\prime \prime} \mathrm{N} \\
92^{\circ} 13^{\prime} 4.2^{\prime \prime} \mathrm{E}\end{array}$ & 2081 & 794.5 & - & 6.6 & 18 & $\begin{array}{l}\text { Black soil in home } \\
\text { garden }\end{array}$ & Blumia spp., Rose \\
\hline Morshing & $\begin{array}{l}27^{\circ} 10^{\prime} 28^{\prime \prime} \mathrm{N} \\
92^{\circ} 12^{\prime} 10.1^{\prime \prime} \mathrm{E}\end{array}$ & 2111 & 792.99 & - & 6.6 & 22 & $\begin{array}{l}\text { Home garden black soil } \\
\text { with pebbles }\end{array}$ & Dhup and Walnut \\
\hline Sanglem & $\begin{array}{l}27^{\circ} 09^{\prime} 42^{\prime \prime} \mathrm{N} \\
92^{\circ} 10^{\prime} 59^{\prime \prime} \mathrm{E}\end{array}$ & 2375 & 769.4 & 9.5 & 6.1 & 20.2 & $\begin{array}{l}\text { Litter soil with bamboo } \\
\text { root, black in colour }\end{array}$ & $\begin{array}{l}\text { Illicium and Rasu } \\
\text { bamboo }\end{array}$ \\
\hline Sanglem & $\begin{array}{l}27^{\circ} 09^{\prime} 47^{\prime \prime} \mathrm{N} \\
92^{\circ} 11^{\prime} 09^{\prime \prime} \mathrm{E}\end{array}$ & 2330 & 774.3 & 8.9 & 6.5 & 15 & $\begin{array}{l}\text { Litter soil } \\
\text { Top soil black } \\
\text { Bottom soil yellowish }\end{array}$ & $\begin{array}{l}\text { Illicium and } \\
\text { Konsainasiang }\end{array}$ \\
\hline Sanglem & $\begin{array}{l}27^{\circ} 09^{\prime} 42^{\prime \prime} \mathrm{N} \\
92^{\circ} 11^{\prime} 16^{\prime \prime} \mathrm{E}\end{array}$ & 2271 & 779.5 & 8.5 & 6.7 & 9.5 & $\begin{array}{l}\text { Litter soil } \\
\text { Top soil black } \\
\text { Bottom soil yellow }\end{array}$ & $\begin{array}{l}\text { Rhododendron, } \\
\text { Quercus spp. }\end{array}$ \\
\hline Sanglem & $\begin{array}{l}27^{\circ} 09^{\prime} 59^{\prime \prime} \mathrm{N} \\
92^{\circ} 11^{\prime} 23^{\prime \prime} \mathrm{E}\end{array}$ & 2209 & 785.2 & 10 & 6.6 & 10 & $\begin{array}{l}\text { Litter soil } \\
\text { Top soil black } \\
\text { Bottom soil brown }\end{array}$ & $\begin{array}{l}\text { Quercus spp. \& } \\
\text { Saqchumaisiang }\end{array}$ \\
\hline Sanglem & $\begin{array}{l}27^{\circ} 10^{\prime} 96^{\prime \prime} \mathrm{N} \\
92^{\circ} 11^{\prime} 40^{\prime \prime} \mathrm{E}\end{array}$ & 2112 & 793.7 & 8 & 4.8 & 43 & Sandy soil, black & $\begin{array}{l}\text { Subusiang (paper } \\
\text { plant), }\end{array}$ \\
\hline $\begin{array}{l}\text { Domkho } \\
\text { (Garden) }\end{array}$ & $\begin{array}{l}27^{\circ} 10^{\prime} 28^{\prime \prime} \mathrm{N} \\
92^{\circ} 12^{\prime} 46^{\prime \prime} \mathrm{E}\end{array}$ & 2017 & 795.5 & 10 & 6.2 & 22 & $\begin{array}{l}\text { Blackish brown soil } \\
\text { covered with grass }\end{array}$ & $\begin{array}{l}\text { Taxus, apple, kiwi, } \\
\text { Artemisia }\end{array}$ \\
\hline Mandala top & $\begin{array}{l}27^{\circ} 16^{\prime} 21^{\prime \prime N} \\
92^{\circ} 15^{\prime} 37^{\prime \prime} \mathrm{E}\end{array}$ & 3185 & 694.5 & 1 & 6.5 & 46 & Litter soil, black & $\begin{array}{l}\text { Rhododendron, } \\
\text { Wansiang }\end{array}$ \\
\hline Mandala & $\begin{array}{l}27^{\circ} 18^{\prime} 05^{\prime \prime} \mathrm{N} \\
92^{\circ} 15^{\prime} 37^{\prime \prime} \mathrm{E}\end{array}$ & 2779 & 731.7 & 3 & 5.1 & 42.5 & $\begin{array}{l}\text { Litter soil, dark brown } \\
\text { (top), Reddish brown } \\
\text { (bottom) }\end{array}$ & $\begin{array}{l}\text { Illicium, Taxus, fern, } \\
\text { Mansiang }\end{array}$ \\
\hline Average & & 2306.17 & 774.82 & 7.36 & 6.11 & 26.52 & & \\
\hline \multicolumn{2}{|c|}{ Standard Deviation } & 344.49 & 31.12 & 3.42 & 0.63 & 13.14 & & \\
\hline \multicolumn{2}{|c|}{ Coefficient of Variation (\%) } & 14.94 & 4.02 & 46.50 & 10.25 & 49.55 & & \\
\hline
\end{tabular}




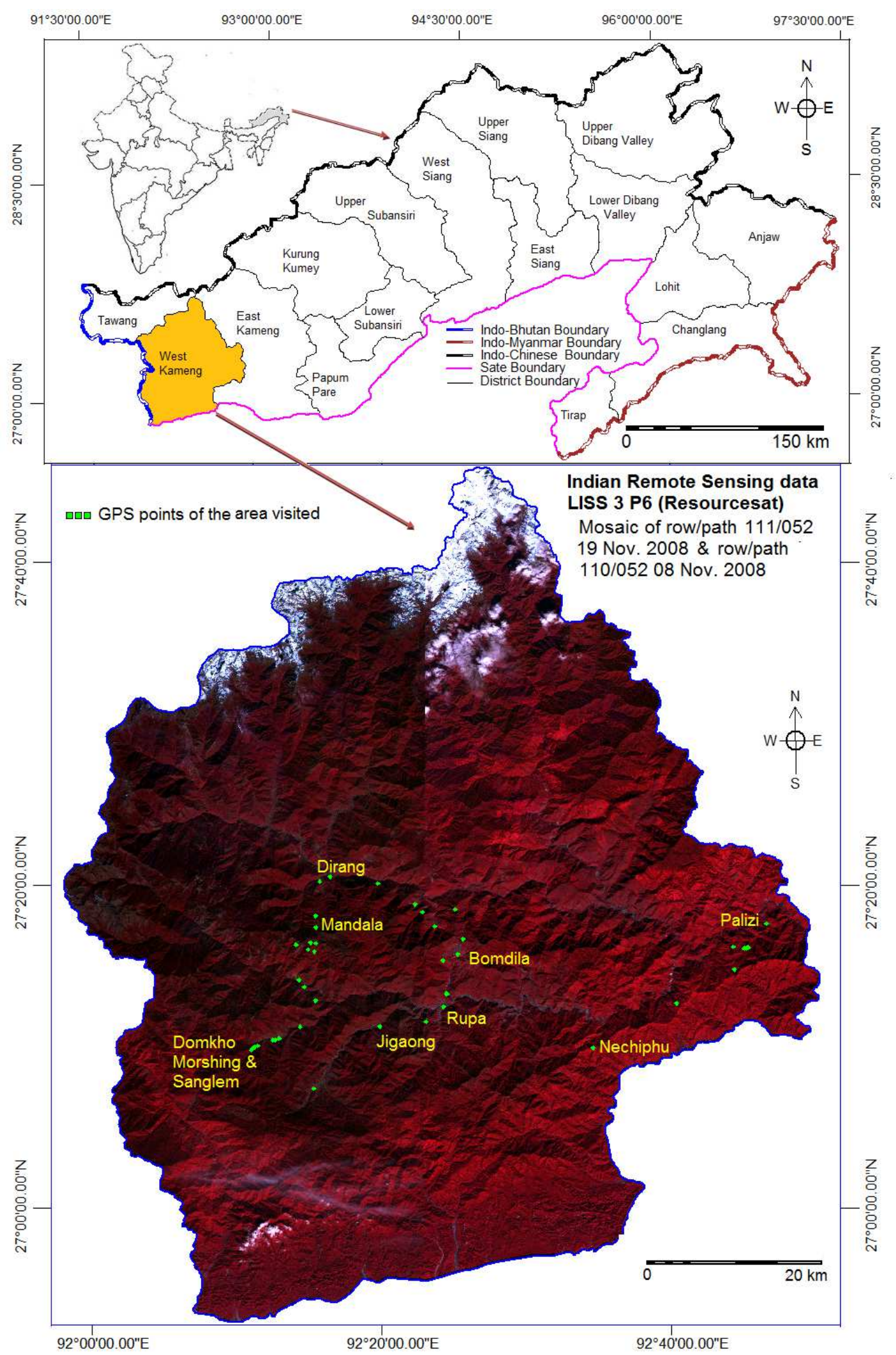

Figure 1. Location map of West Kameng district.

For conservation efforts of the plant a workshop has been conducted in Domkho village near Morshing where large scale exploitation has been observed. During the workshop the villagers were educated about the importance of the tree, its vulnerability and present condition at global, national and local levels (Figure 3). They are also encouraged to protect and regenerate the tree species. Plant trees in the sacred areas, plant five seedlings for cutting one tree, plant trees during important ceremonies like marriage, death ceremony and anniversaries, explication of chipko movement, etc were the 
measure suggested to regenerate the plant. The plants grown in the sacred places like temples are generally regarded as sacred or having some religious significance, which in turn would help in protecting the plant species. The trees planted during important ceremonies imbibe an emotional attachment of community which is always protected and respected by them. With this view the workshop was followed by the plantation of the Taxus saplings around the Gompas or other sacred places.

In the workshop pamphlets containing information on targeted plant species were distributed to the villagers and the schools and offices to generate mass awareness. Similar information were inscribed in the New Year calendar and distributed to each household in the villages. The poster containing inscribed messages like "Do not kill me, Cancer may kill you" and "Help! Me to grow up, I may help you in curing cancer" both in English and local languages were displayed in the crucial points. During the pilot survey, many saplings of Taxus were located in the secondary forest of Mandala area. A brief interaction was, therefore, carried out about the importance of the targeted plants with the personnel of Indian Army on duty in Mandala area for survey. The insitu trial of seed germination in Sanglem village and transplantation at Palizi shows positive responses. About 20 seedlings from the nursery of National Medicinal Plant Board, Bomdila were procured and transplanted in the Botanic Garden in Rajiv Gandhi University (RGU), Rono Hills. The ex-situ trial in the RGU campus also shows a positive response at the initial stage (Figure 4).

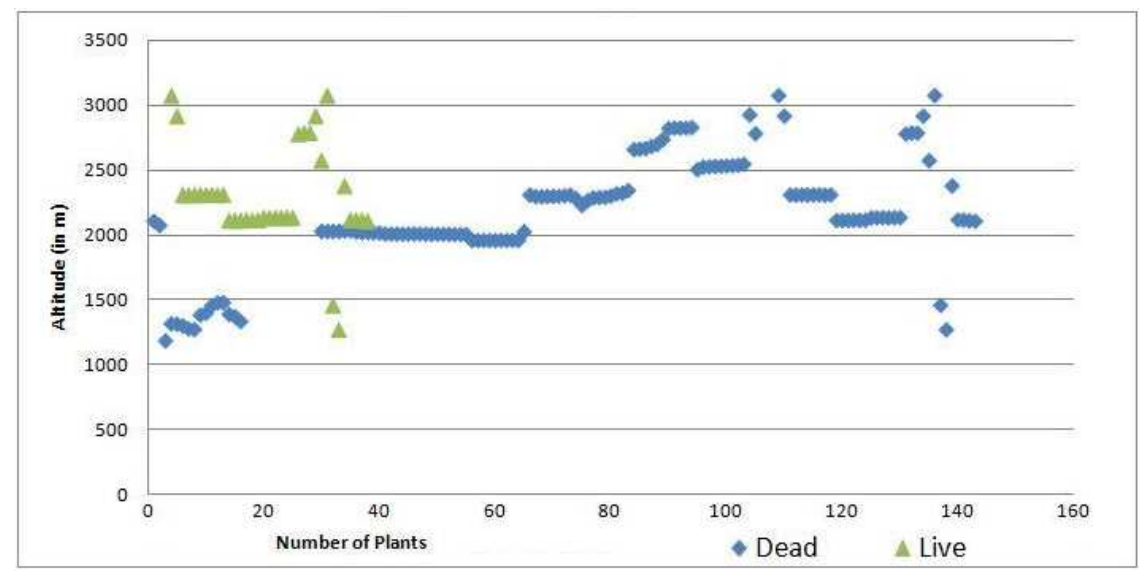

Figure 2. Scattered diagram showing altitude-wise dead and live Taxus plants.

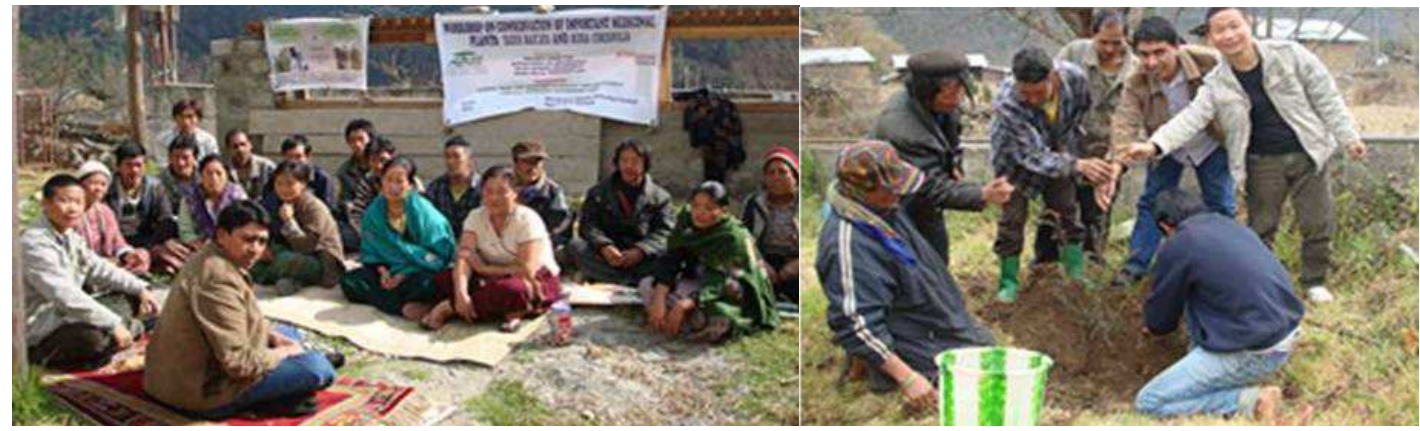

(a)

(b)

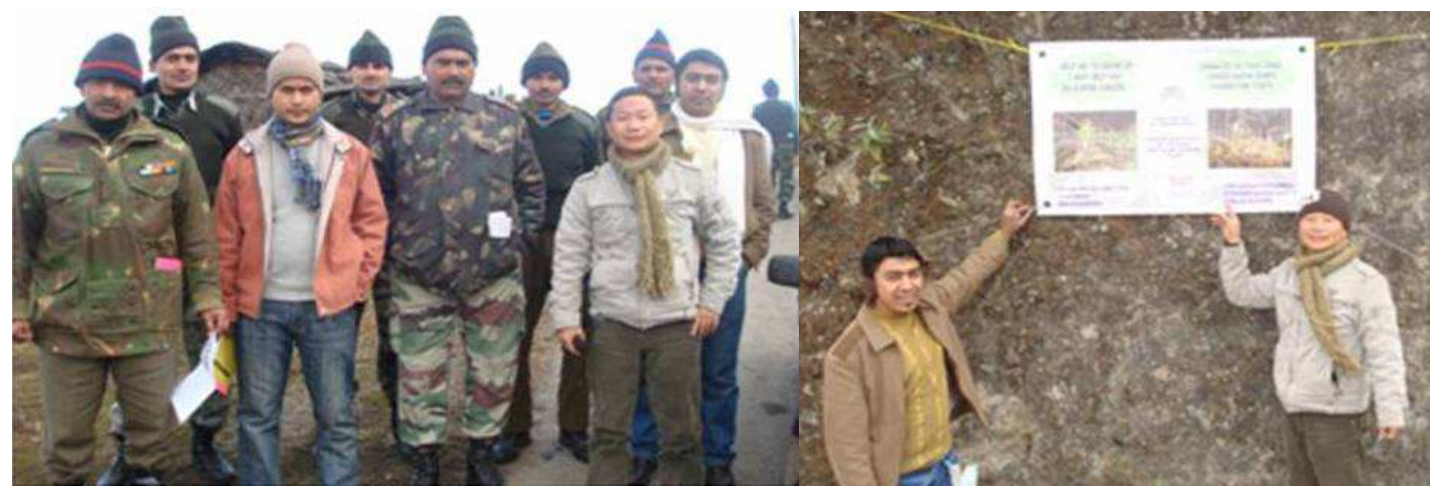

(c)

(d)

Figure 3. (a) Workshop in Domkho village, (b) Taxus plantation in Domkho, (c) Awareness campaign with Army personnel, (d) Poster display for awareness. 


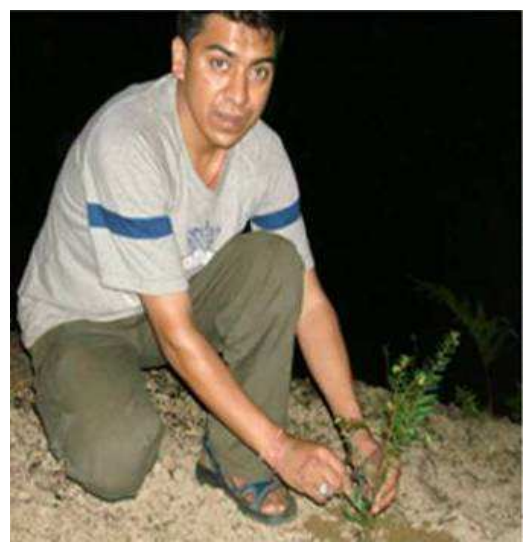

(a)

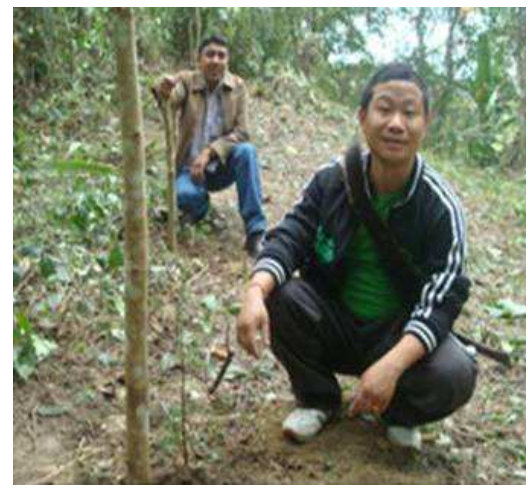

(c)

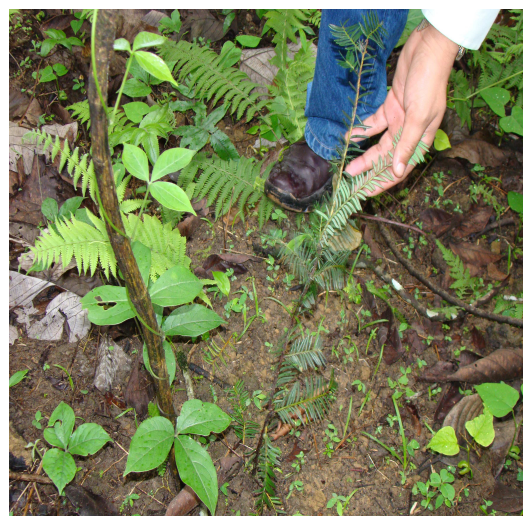

(e)

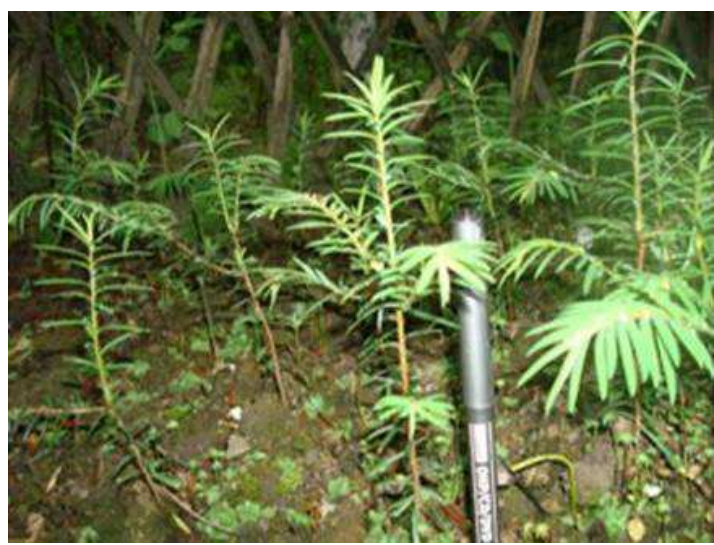

(b)

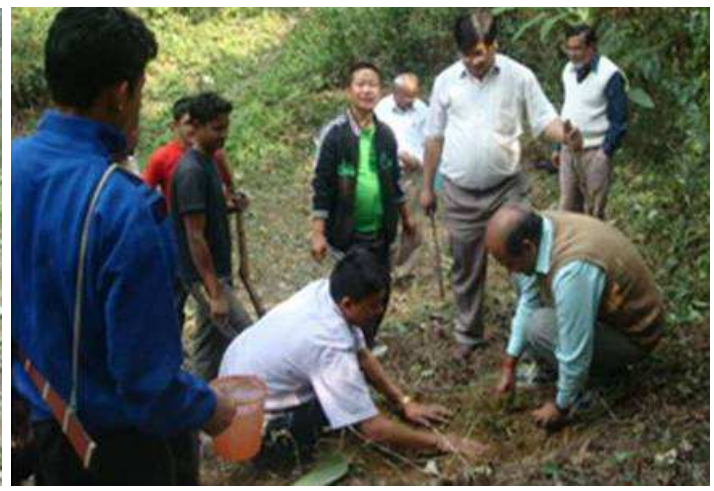

(d)

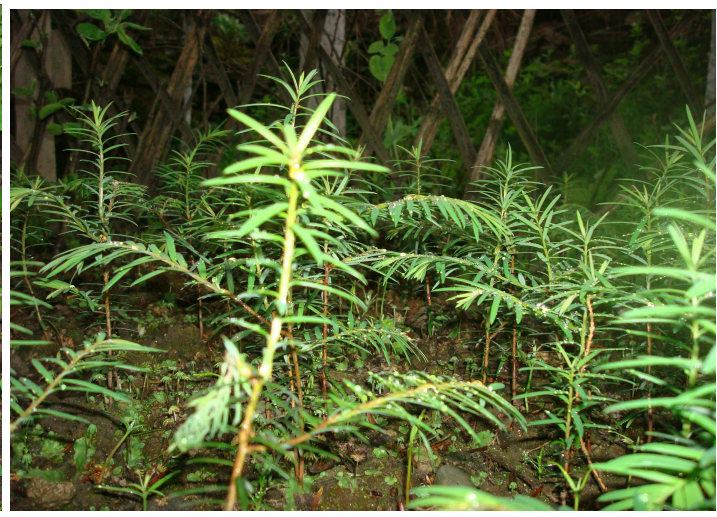

(f)

Figure 4. (a) In-situ trial at Palizi, (b) In-situ trial at Morshing, (c), (d) \& (e) ex-situ trial in the botanic garden of RGU, (f) In-situ trial at Sanglem.

\section{Discussion}

In Domkho, Morshing, Sanglem, Khelang, Phudung, Mandala and Dirang areas large scale exploitation of Taxus plants has taken place during 1990s. During the interaction with village elders, herdsmen, hunters, local body members, etc. it was reported that Taxus (locally known as Tesiang or Tesing) was abundantly available in nearby forest. But, after the large scale supply of leaves, it is now not found within 8 to $10 \mathrm{~km}$ radius from these villages. The linear transacts in the deep forests around the villages reveals many dead Taxus trees (Figure 5). In the absence of standard lopping methods, the leaves were pruned mercilessly to the extent that plant could not withstand to survive. Moreover, the pressing demands and associated lucrative price lured middlemen and villagers to plunder this scarce resource pushing it to the extreme limits of disappearance. The complete dryness of all harvested plants in the area, speaks a volume about the unscrupulous way of exploitation for commercial purpose turning these area into a 'grave yard' of this valuable species. Apart from the absence of standard lopping techniques, it also reveals non-existence of any regulatory mechanisms for sustainable harvest. The interaction with the villagers, during workshop revealed that about 70 to 80 trucks of Taxus leaves were supplied each from Domkho, Morshing and Sanglem villages. One truck of the Taxus would need at least 30 fully 
grown trees to be completely pruned. Thus, around 9600 full grown trees have been completely destroyed from these three villages. The villagers in the workshop expressed their ignorance about the importance and vulnerability of the tree. They also reported that in the beginning, although some portion of the canopy were left for sustainable re-growth of plant, but eventually those leftovers were also lopped down due to the high demands. Surprisingly, even the seedlings or the young plants are conspicuous by their absence in the vicinity of dried up trees. This confirms the reported poor regeneration, germination and survival rates of the plant [3]. However, there could be many reasons attributed to this phenomenon. Firstly, the dense nature of forest with thick undergrowth may have prevented the growth of seedlings as the natural regeneration is reported well in broken canopy. Second possible reason may be the browsing of wild animals, cattle and fowls. Thirdly, the illegal trade also cannot be ruled out going under hand in the area.

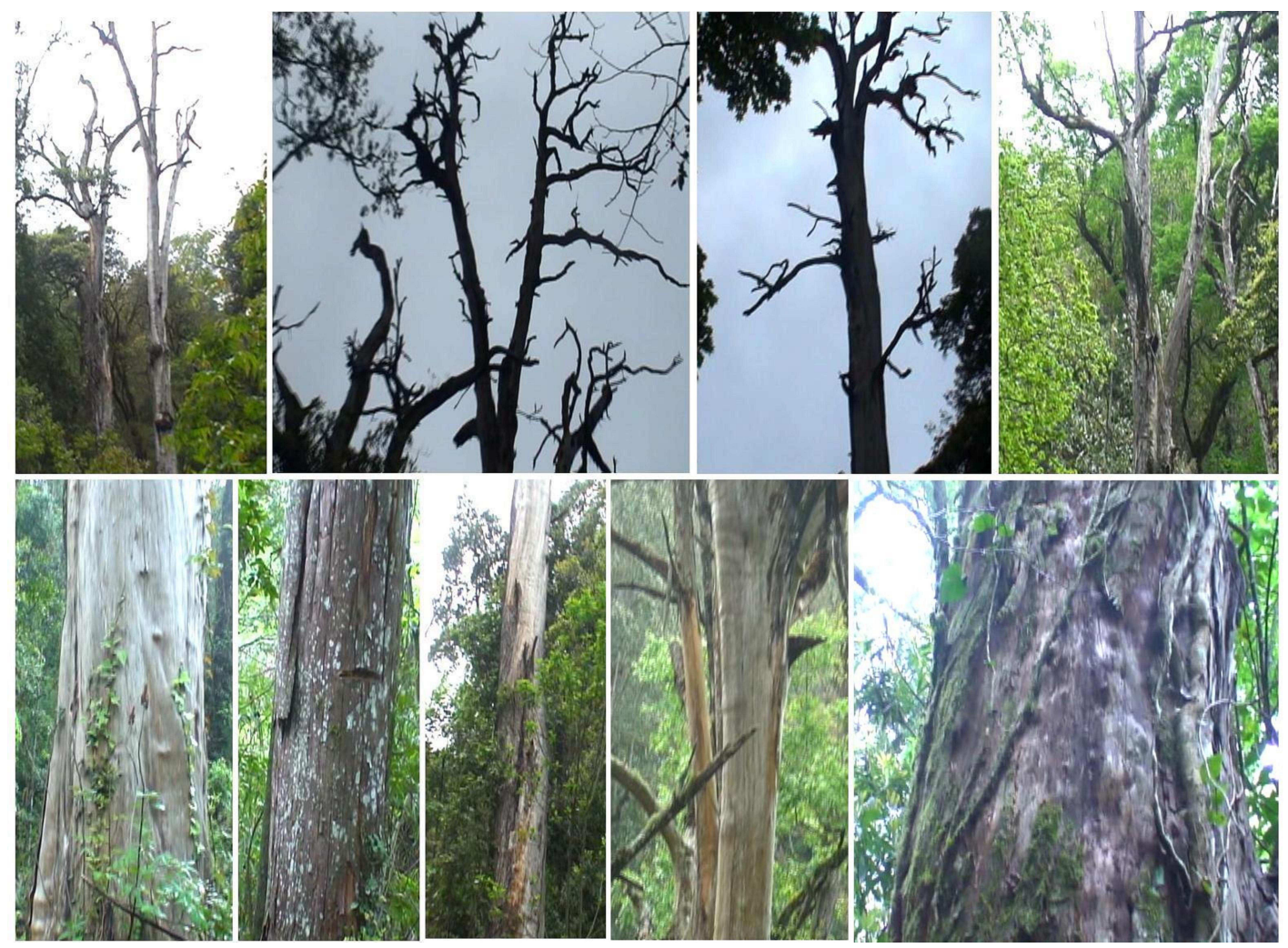

(a)

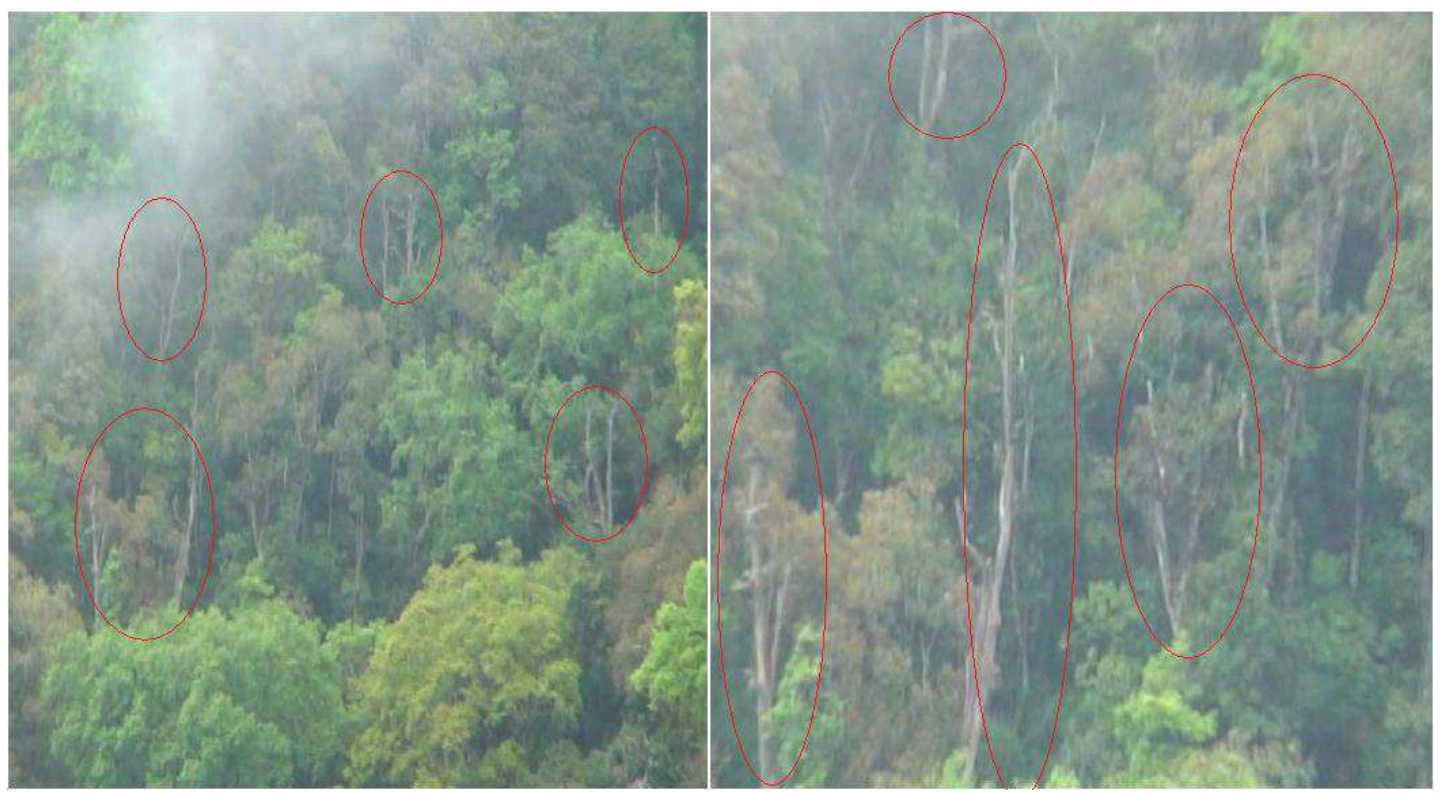

(b)

Figure 5. (a) Dead Taxus trees on the aftermath of reckless exploitation, (b) Dead stumps of Taxus trees in the dense forest. 
A clandestine trading in the species is taking place in some states where young saplings raised by the locals are being collected by the agents and sold abroad through an established network. According to Grassroots Options (2002) Assam forest officials at Tezpur seized 220 bags of Taxus leaves loaded in three trucks from Arunachal Pradesh which strongly suggest deeply entrenched nexus of politicians, contractors and forest officials operating in Arunachal Pradesh. The investigation by Grassroots Options reveals that M/S Arunachal Pradesh Herbal Company Private Ltd., a local firm in the West Kameng District had entered a lease agreement with the state forest department in November 2001 to collect Taxus leaves from the forests in West Kameng and Tawang districts for 15 Years.

There are some semi-nomadic people in the area known as Brokpas who lives on transhumance herding. They migrate seasonally between the alpine grasslands and pastures of low lying areas along with their herds. During winter they descend down to low lying areas and in summer they climb towards alpine grasslands. The practice of transhumance pastoralism also demands pasture lands (Brok) for the Yak and other cattle in different altitudes which is the major cause of forest degradation in general and loss of valuable temperate species in particular. The increasing demand of pasture land is met by clearing forest and setting fire into it which sometimes causes uncontrollable forest fire. Fire is also set in the forest during dry season to burn undergrowth or ground cover of pine leaves which help in the growth of tender grasses for cattle and wild animals. It reveals yet another dimension of the prevailing anthropogenic threat to this important plant from within the region through deliberate action for fodder and pastures. In the context of rapid changes owing to such forest losses, vegetation cover and species population is expected to decrease over small spatial scale [24]. The excessive species loss could also lead to collapse of the ecosystem [25]. Further, shortening of jhum cycle from the traditional 10 years or more to $4-5$ years on an average now is indeed a matter of concern [26]. In fact, habitat fragmentation which is a typical consequence of human activities negatively impacts yew pollination and fitness because formation of viable seeds requires that individuals of both sexes co-exist on the landscape (yew is a dioeceous species). Land use changes are also likely to have contributed to shrinking yew habitat, through logging of oldgrowth stands, often in combination with grazing and burning [27]. Such activities have transformed the forest landscape and affected vegetation dynamics, especially of shade-tolerant and late-successional species such as yew [28, 29].

Although leaves of the tree is used traditionally since time immemorial to feed the Yak, yet the tree would die once its leaves are extracted was not known to them, the villagers lamented during the workshop. There was no rule and regulations or instructions and standardize method of the exploitation from the Government's or department's side. Wherever the Taxus trees are found, irrespective of its size, cut the leaves and sell off as the order of the day. However, the profits are being garnered mainly by the drug manufacturers and middlemen, to the neglect of the local people [23]. Although this slow growing plant produces resistant hard wood, the study shows that it is very delicate to survive without adequate canopy unlike other coniferous trees. The extensive and indiscriminate exploitation of Taxus baccata has posed a serious threat to this important Himalayan tree [22, 30]. Degradation of old populations and low regeneration in its natural habitat are the main problems in the conservation of Taxus baccata. Low regeneration and recruitment of this species are because of grazing of browsing animals, chilling injury, direct sunlight and fire, which are common in the Himalayan region [8]. Although few saplings and seedlings were also found in these areas, but their numbers are very less and found sparsely scattered and isolated. Some of the villagers in Domkho and Morshing villages have also ventured to cultivate Taxus plants in the farmyards. However, the rate and scale is very insignificant to compensate the irreparable loss met to this resource. These planted Taxus are seen bearing cones during the field survey.

A villager named Pema Tashi from the Morsing village is growing Taxus plants in his kitchen garden, horticulture garden and along the fences of his field. Every year he collects Taxus seeds and grows it in a small nursery and transplants it to other suitable areas. As per his practical experience he reported that there is very poor success rate of the Taxus seeds and seedlings. He took up this challenging task by his own inspiration and by the solace his family received from the Taxus plant. He sold the dried raw Taxus leaves@Rs.3 perkg and the dried leaves@of Rs.27 per $\mathrm{kg}$. He wants to take up this task in a broad scale if provided with some financial assistance from the government or other concerned agencies. Workshops at the grass root level is an effective means of educating the villagers which facilitates direct and close interaction with them. At the same time it is very difficult task to reach each and every village, especially in the area like Arunachal Pradesh. Workshops were conducted at the grass root level i.e. for creating awareness among the villagers about the importance, utility and vulnerability of the target plant species so as to protect its further reckless exploitation. Secondly, it envisaged to encourage the villagers to regenerate the plants, especially Taxus baccata in the areas where it is easy to grow with minimum efforts. Taxus do not grow under the dense canopy and in the areas which are easily accessible to browsing animals. The degraded forests inaccessible to animals, fenced gardens and religious places like temple premises are the suitable areas for regeneration of Taxus. During the workshop the villagers are educated about the importance of the tree, its vulnerability and present condition at global, national and local levels and encouraged to protect and regenerate the tree species. The plants grown in the sacred places like temples are generally regarded as sacred or having some religious significance, which in turn would help in protecting the plant species. The trees planted during important ceremonies 
imbibe an emotional attachment of community which is always protected and respected by them. The awareness campaign for the importance and need for conservation of Taxus throughout the district seems to have received good response. The distribution of pamphlets containing basic information, importance and conservation slogans of the plants has been appreciated by the entire people. The calendar with the slogan "Save Taxus Fight Cancer" is well received by the people that might have greater implications in conservation efforts of the plant.

\section{Concluding Remarks}

The rampant exploitation of the Taxus has occurred in many areas of West Kameng District of Arunachal Pradesh during the 1990s. Since no regulatory mechanism and standardized harvesting techniques were adopted, the trees dried up once its leaves were harvested. This has pushed this valuable resource to the extreme limit of extinction from the area. Consequently, Taxus in a natural stand is not available in the vicinity of Domkho, Morshing, Sanglem, Khelang, Phudung, Mandala, Dirang, Bomdila and Palizi-Ramda. There are no systematic approaches made in order to regenerate this species through the active participation of the communities and the people themselves are also not coming forward to take up such challenges. No doubt, the State Forest Research Institute (SFRI) and National Medicinal Plant Board have started nursery and propagation trials near Bomdila. But, the nursery is in pathetic condition in the absence of care, maintenance, transplantation and lack of workers.

Thus, the findings shows adverse effects of exploitation on Taxus plant, very poor natural regeneration of plant, localized natural growth and no tangible efforts to regenerate the stock. The regeneration of the plant involves risk and uncertainty to the villagers. Besides, there is need of special care and additional financial involvement in providing proper fencing to protect the plant from browsing animals. Therefore, there is an urgent need of concrete steps for conservation and regeneration of this vanishing valuable resource. This can be achieved by systematic strategies through larger community awareness, community participation, suitable propagation techniques, in-situ and ex-situ trials, demonstration, financial and infrastructural assistance, adequate remuneration, etc. Since the growth of plant and its survival rate are very low, the regeneration of the plant involves risk and uncertainty to the villagers. Moreover, the regeneration also needs proper protection (fencing) against browsing animals feeding on the plants. Because of all these practicalities the farmers are reluctant to regenerate Taxus plants by their own even if it has great demand in the pharmaceutical industries. Therefore, more focus is needed on the financial assistance and remuneration to the growers to ensure large scale participation. More importantly, there is also a need of regulatory mechanism and standardized harvesting techniques for the sustainable use of this resource.

\section{Acknowledgements}

The authors are thankful to the villagers of West Kameng district of Arunachal Pradesh (India) for the cooperation and participation in the project works. We are also grateful to the Ashoka Trust for Research in Ecology and the Environment, Darjeeling and Critical Ecosystem Partnership Fund for funding a major project on the status and conservation of Taxus baccata Linn.

\section{Funding Body}

Ashoka trust for research in ecology and the environment, Darjeeling and critical ecosystem partnership fund.

\section{References}

[1] D. Phillips, D. B. Dwyer and Dabur Research Foundation, "Sustainable harvesting of Himalayan yews," in Medicinal plant trade in Europe: conservation and supply, TRAFFIC EUROPE, Eds. Cambridge: Europe, 1998, pp. 147-154.

[2] Z. Saqib, R. N. Malik, and S. Z. Husain, "Modeling potential distribution of Taxus wallichiana in Palas Valley, Pakistan." Pak. J. Bot., vol. 38(3), pp. 539-542, 2006.

[3] B. S. Beniwal and K. Haridasan, "Natural Distribution and status of regeneration of Gymnosperms in Arunachal Pradesh," Ind. Forester, vol. 118, pp. 96-101, 1992.

[4] S. K. Nandi and L. M. S. Palni, "Common Yew - a Himalayan assets under threat: Successful rooting of cuttings," HemaParyavaran, vol. 5, pp. 8-9, 1993.

[5] G. P.Shukla, K. Rao and K. Haridasan, "Taxus baccata in Arunachal Pradesh," Arunachal Forest News, vol. 12(1), pp. 1-7, 1994.

[6] K. C. Sahni, Gymnosperms of India and adjacent countries. BSMPS Publishers: Dehradun, 1990.

[7] M. C. Wani, H. L. Taylor, M. E. Wall, P. Cogon and A. T. Mcphail, "Plant antitumor agents. VI. Isolation and structure of taxol, a novel antileukemic and antitumor agent from Taxus brevifolia," J. Am. Chem. Soc., vol. 93, pp. 1325-1327, 1976.

[8] A. Purohit, R. K. Maikhuri, K. S. Rao and S. Nautiyal, "Impact of bark removal on survival of Taxus baccata L. (Himalayan yew) in Nanda Devi Biosphere Reserve, Garhwal Himalaya, India," Curr. Sci., vol. 81(5), pp. 586-590, 2001.

[9] A. Stierle, G. Strobel and D. Stierle, "Taxol and taxane production by Taxomyces andreanae, an endophytic funguan of Pacific Yew," Sci., vol. 260, pp. 214-222, 1993.

[10] J. Ge, W. Ping and D. Zhou, "Characterization of a New Species of Taxol-producing Fungus," Nature Sci., vol. 2, pp. 85-88, 2004.

[11] S. I. Cameron and R. F. Smith, "In Bringing 'Blue Sky Biology' Down to Earth: Linking Natural Products Research with Commercialization," in Proc. 29th Annual Meeting of the Plant Growth Regulation Society of America, N. S. Halifax, Eds., 2002, pp. 31-39.

[12] G. A. Strobel, W. M. Hess, E. Ford, R. S. Sidhu and X. Yang, "Taxol from fungal endophytes and the issues of biodiversity," J. Ind. Microbiol., vol. 17, pp. 417-423, 1996. 
[13] J. F. Wang, "Taxol from Tubercularia sp. Strain TF5 an endophytic fungus of Taxus mairei," FEMS Microbiol. Letters, vol. 193, pp. 2223-2226, 2000.

[14] D. P. Zhou, et al, "Nolulisporium, a genus new to China," Mycosystema, vol. 20, pp. 148-150, 2001.

[15] J. Y. Li, G. A. Strobel, R. Sidhu, W. M. Hess and E. Ford, "Endophytic taxol producing fungi from bald cypress Taxodium distichum," Microbiol., vol. 142, pp. 2223-2226, 1996.

[16] B. H. Guo, Y. C. Wang, X. W. Zhou, K. Hu, F. Tan, Z. Q. Miao and K. X. Tang, "An endophytic taxol-producing fungus BT2 isolated from Taxus chinensis var. Mairei," Afr. J. Biotechnol., vol. 5, pp. 875-877, 2006.

[17] F. Xu, W. Tao, L. Chang and L. Gou, "Strain improvement and optimization of the media of taxol-producing fungus Fusarium maire," Biochem. Engineering J., vol. 31, pp. 67-73, 2006.

[18] J. I. Yuan, B. I. Jian-Nan, Y. Bing and Z. Xu-Dong, "Taxolproducing fungi: a new approach to industrial production of taxol," Chin.J. Biotechnol., vol. 22, pp. 1-6, 2006.

[19] B. V. S. K. Chakravarthi, P. Das, K. Surendranath, A. A Karande and C. Jayabaskaran, "Production of paclitaxel by Fusarium solani isolated from Taxus celebica," J. Biosci., vol. 33, pp. 259-267, 2008.

[20] D. Frense, "Taxanes: perspective for biotechnological production," Applied Microbiol. Biotechnol., vol. 73, pp. 1233-1240, 2007.

[21] V. Gangadevi, M. Murugan J. And Muthumary, "Taxol Determination from Pestalotiopsis pauciseta, a Fungal Endophyte of a Medicinal Plant," Chin. J.Biotechnol., vol. 24, pp. 1433-1438, 2008.

[22] S. K. Nandi, L. M. S. Palni and H. C. Rikhari, "Chemical induction of adventitious root formation in Taxus baccata cuttings," Plant Growth Regulation, vol. 19, pp. 117-122, 2006.

[23] A. Khanna, "Himalayan Yew to fight Cancer," Down to Earth, vol. 2, p. 41, 1994.

[24] A. Agarwal, and G. Srivastava, "Forest destruction in Eastern Himalayas,” Curr. Sci., vol. 94(1), pp. 8, 2008.

[25] R. Kanade, M. Tadwalkar, C. Kushalappa and A. Patwardhan, "Vegetation composition and woody species diversity at Chamoli NP, North Western Ghats, India," Curr. Sci., vol. 95(5), pp. 637-646, 2008.

[26] P. Pokhriyal, V. Naithani, S. Dasgupta, and N. P. Todaria, "Comparative studies on species richness, diversity and composition of Anogeissus latifolius mixed forests in Phakot and Pathri Rao watersheds of Garhwal Himalaya," Curr. Sci., vol. 97(9), pp. 1349-1355, 2009.

[27] G. Piovesan, E. P. Saba, F. Biondi, A. Alessandrini, A. Filippo and B. Schirone, "Population ecology of yew (Taxus baccata L.) In the Central Apennines: spatial patterns and their relevance for conservation strategies," Plant Ecol., DOI 10.1007/s11258-009-9596-1, 2009.

[28] R. T. Busing, C. B. Halpern and T. A. Spies, "Ecology of Pacific yew (Taxus brevifolia) in western Oregon and Washington," Conserv. Biol., vol. 9, pp. 1199-1207, 1995.

[29] C. Kwit, C. C. Horvitz and W. J. Platt, "Conserving slowgrowing, long-lived tree species: input from the demography of a rare understory conifer, Taxus floridana," Conserv. Biol., vol. 18, pp. 432-443, 2004.

[30] R. P. Khali, Ecological studies on Taxus baccata Linn. In relation to regeneration and conservation, $\mathrm{Ph}$ D Thesis, FRI Deemed University, Dehradun, 2001. 